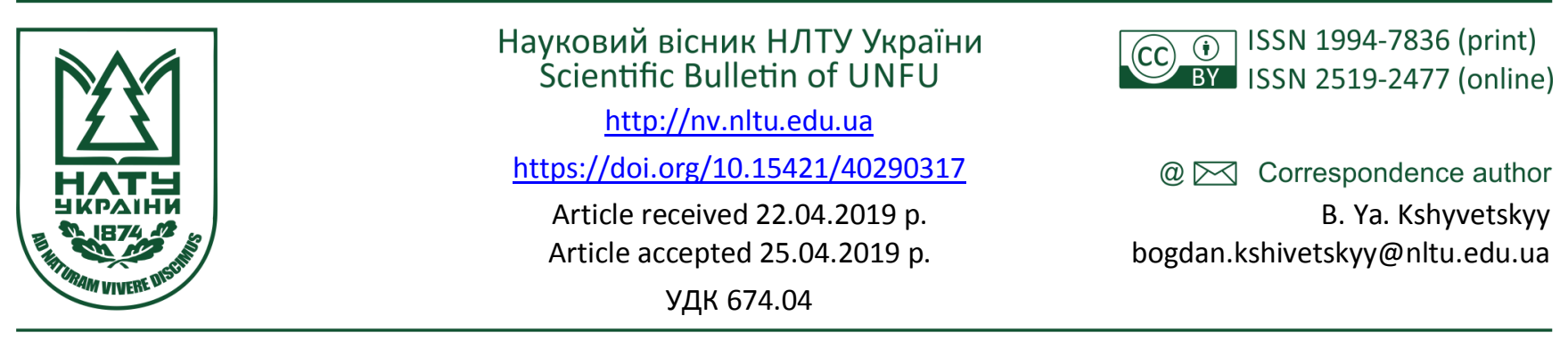

Б. Я. Кшивецький, Г. М. Дацків, Й. В. Андрашек

Національний лісотехнічний університет України, м. Львів, Украйна

\title{
ЗАГАЛЬНІ ВІДОМОСТІ ПРО КЛЕЇ, СКЛЕЮВАННЯ ТА ТЕРМІЧНО МОДИФІКОВАНУ
} ДЕРЕВИНУ

\begin{abstract}
Наведено аналіз клеїв, які використовують для склеювання деревини у деревообробному і меблевому виробництвах, зважаючи на їх екологічність, токсичність, походження, економічність, способи виробництва і сфери застосування. Особливу увагу приділено термопластичним полівінілацетатним клеям, які є одними з найперспективніших на сьогодні для склеювання як звичайної, так і термічно модифікованої деревини. В умовах зростання вимог до екологізації промисловості та обмежень використання матеріалів, що містять шкідливі хімічні компоненти, виникла потреба у розробленні нових методів модифікування деревини, які базувались би на принципах екологічності та ресурсоощадності. Показано, що за дії на деревину температури $180-240{ }^{\circ} \mathrm{C}$ в іiі біологічному складі відбуваються незворотні зміни, які впливають на властивості кінцевого продукту, зокрема: покращена формостійкість та стійкість до високих температур, абсолютна стійкість до біологічних уражень, висока вологостійкість (адсорбційні властивості у 3-5 разів нижчі, ніж у звичайної деревини), однорідність кольору за глибиною, довговічність, екологічність тощо. Усі зазначені вище властивості термічно модифікованої деревини зумовлюють універсальність їі використання: як конструкційного матеріалу, стійкого до атмосферних впливів (вуличні конструкції, ландшафтний дизайн, будівництво мостів, причалів, облицювання водних каналів), для зовнішнього та внутрішнього оздоблення фасадів та житлових приміщень, виготовлення меблів, підлогового покриття, музичних інструментів тощо. Сфера застосування термодеревини така ж широка, як і сфера застосування звичайної деревини. Зокрема, з термічно модифікованої деревини можна виготовляти малі архітектурні форми, садово-паркові конструкції. Одним з пріоритетних напрямів наукових досліджень є вивчення термодеревини, що може використовуватися як матеріал для несних конструкцій. Зокрема, у вигляді композитного клеєного бруса ("клеєний термобрус"), що об'єднує ламелі з модифікованої та звичайної деревини. Наведено аналіз впливу зміни фізико-механічних властивостей термічно модифікованої деревини на міцність та довговічність клейових з'єднань.
\end{abstract}

Ключові слова: клеї; термічно модифікована деревина; склеювання; міцність; довговічність.

Вступ. Розвиток деревообробного виробництва сприяє інтенсифікації процесів склеювання, розробленню та модифікуванню нових клейових матеріалів та з'єднань на їх основі, які враховують екологічні аспекти сьогодення. Клеї, які використовують для склеювання деревини та деревинних матеріалів, поділяють на клеї природного походження та синтетичні клеї. До клеїв природного походження відносять білкові, а саме: казеїнові, альбумінові, колагенові, і вуглеводні, а саме: крохмальні та декстринові. Клеї синтетичного походження поділяють на конденсаційні і полімеризаційні. За відношенням до температури їх класифікують на термопластичні і термореактивні. Така термінологія класифікації клеїв набула значного поширення. Термопластичні клеї під час нагрівання й охолодження здатні багаторазово переходити із в'язкотекучого стану в твердий. Термореактивні - формують тверде та крихке клейове з'єднання.

Для склеювання деревини та деревинних матеріалів використовують як термореактивні, так і термопластич- ні клеї. Перші набули ширшого використання для склеювання деревини, клейове з'єднання якої буде експлуатуватися при зміні вологості та температури, а другі в середині приміщень. Це зумовлено стійкістю клейового з'єднання до дії вологості та температури. Клейові з'єднання на термореактивній основі $є$ стійкіші до дії вологи та температури, але є крихкими та токсичними. Клейові з'єднання на термопластичній основі $є$ менш стійкими до дії вологості та температури, але разом 3 тим є менш токсичними, більш еластичними.

Склеєну деревину широко використовують для виготовлення меблевих, столярно-будівельних виробів, домобудування, для виготовлення клеєного бруса, паркетної дошки тощо. Основними вимогами, які ставлять до клеєної деревини, є належна міцність, довговічність та екологічність під час іiї експлуатації.

Мета роботи - виконати аналіз наявних клеїв, що використовують у деревообробних виробництвах, встановити можливість їх використання для склеювання

Інформація про авторів:

Кшивецький Богдан Ярославович, д-р техн. наук, професор, завідувач кафедри технологій захисту навколишнього середовища, деревини, безпеки житєдіяльності та соціальних комунікацій. Email: bogdan.kshivetskyy@nltu.edu.ua

Дацків Галина Миколаївна, ст. лаборант, кафедра технологій меблів та виробів з деревини. Email: Datskivhalyna12@gmail.com

Андрашек Йосип Володимирович, канд. техн. наук, доцент, кафедра технологій захисту навколишнього середовища, деревини, безпеки життєдіяльності та соціальних комунікацій. Email: joseph.andrashek@nltu.edu.ua

Цитування за Дсту: Кшивецький Б. Я., Дацків Г. М., Андрашек Й. В. Загальні відомості про клеї, склеювання та термічно модифіковану деревину. Науковий вісник НлтУ України. 2019, т. 29, № 3. С. 81-84.

Citation APA: Kshyvetskyy, B. Ya., Datskiv, H. M., \& Andrashek, Yo. V. (2019). General information about adhesives, gluing, and thermally modified wood. Scientific Bulletin of UNFU, 29(3), 81-84. https://doi.org/10.15421/40290317 
термічно модифікованої деревини і розробити завдання досліджень для вирішення проблемних питань склеювання звичайної і термічно модифікованої деревини.

Аналіз та класифікація клеїв для склеювання деревини. Клей - речовини або суміші речовин органічної або неорганічної природи, що внаслідок притаманним їм специфічним властивостям, за певних умов, здатні утворювати міцні з'єднання різноманітних матеріалів і $є$ тим зв'язком, яке визначає довговічність з'єднання деревини, забезпечуючи при цьому відповідну адгезійну і когезійну міцність (Prokopovych et al., 2002).

Першими синтетичними клеями були фенолформальдегідні, які широко використовувались для склеювання. Пізніші були синтезовані карбамідоформальдегідні, меламіно-формальдегідні, полівінілацетатні (ПВА) та ін. Для склеювання деревини та деревинних матеріалів використовують близько 75 \% клеїв від загальної кількості їх виробництва. Із них майже $30 \%$ - це клеї на основі полівінілацетату.

3 розвитком асортименту клейових матеріалів постало питання їх класифікації, тобто чіткого поділу за певними ознаками. Загальна їх класифікація відома, запропонована та подана у вигляді структурної схеми, яку наведено на рис. 1 .

Класифікація клеїв для склеювання деревини

\begin{tabular}{|c|c|}
\hline За походженням & За водостійкістю \\
\hline Рослинного походження & Низької водостійкості \\
\hline Тваринного походження & Середньої водостійкості \\
\hline Мінеральні & \\
\hline Синтетичні & Високо1 Водост1икост1 \\
\hline За складом & За видом розчинника \\
\hline Однокомпонентні & Водорозчинні \\
\hline Двокомпонентні & Спирторозчинні \\
\hline За способом отримання & За зовнішнім виглядом \\
\hline Поліконденсаційні & Рідкі \\
\hline Полімеризаційні & Пастоподібні \\
\hline Залежно від температури & Плівкові \\
\hline Термореактивні & Порошкоподібні \\
\hline Термопластичні & У вигляді гранул \\
\hline
\end{tabular}

Рис. 1. Класифікація клеїв для склеювання деревини

Зважаючи на адгезію до деревини, еластичність клейового шва, екологічність тощо, найперспективнішими для склеювання деревини є клеї на основі ПВА (GOST 18992-80, 2001). Разом 3 тим до основних недоліків ПВА клеїв відносять їх низьку водостійкість і теплостійкість. Для усунення цих недоліків ПВА клеї модифікують. Тому на сьогодні ПВА клеї можуть бути пластифіковані і не пластифіковані, однокомпонентні і двокомпонентні, мати підвищену водо- та вологостійкість клейових з'єднань (Kshyvetskyi \& Solonynka, 2007).

Підсумовуючи наведене вище, можна зробити висновок, що для склеювання деревини та деревинних матеріалів використовують термопластичні і термореактивні клеї. Термореактивні клеї на сьогодні почали мен- ше використовувати через їх токсичність і досить крихкий клейовий шар. Тому перспективнішими $є$ термопластичні полівінілацетатні клеї, які володіють добрими адгезійними властивостями до деревини, є екологічно безпечними i формують еластичний клейовий шов (Kshyvetskyi \& Tyvunka, 2018).

Термічно модифікована деревина та її властивості. Під термічно модифікованою розуміють деревину, яку піддають тривалому обробленню за підвищених температур, внаслідок чого вона отримує високу стійкість проти біологічних і грибкових ушкоджень, підвищені теплоізоляційні і протипожежні властивості, збільшує свою зносостійкість і довговічність порівняно 3 немодифікованою деревиною. А термічне модифікування деревини можна охарактеризувати як процес спрямованої зміни фізико-механічних властивостей деревини, шляхом іiї витримки за температури $180-240{ }^{\circ} \mathrm{C}$.

Оброблення деревини підвищеною температурою почали вивчати Штам і Хансен у 1930-ті роки в Німеччині і Уайт - у 1940-х роках у Сполучених Штатах (Wood, 2003). Проте промислове виробництво термічно модифікованої деревини розпочалося в 1990-ті роки.

Однією з перших технологій на ринку термічно модифікованої деревини була технологія ThermoWood ${ }^{\circledR}$. Ïï розробниками та реалізаторами є фінські концерни Lunawood Oy, Valutec Oy, італійська компанія Baschild та ін. Для цієї технології характерний тристадійний процес виготовлення матеріалу в середовищі насиченої водяної пари, що є агентом оброблення на всіх стадіях модифікування. Температура модифікування була в межах $185-215^{\circ} \mathrm{C}$. На іiі основі виготовляють два класи продукції: "Thermo S" та "Thermo D". Клас "Thermo S" (від англ. "stable" - стійкість, стабільність). Клас "Thermo D" (від англ. "durability" - довговічність).

Унаслідок термічного оброблення дещо змінюється структура деревини. На рис. 2 показано відмінності у структурі необробленої і термічно модифікованої деревини сосни (Kshyvetskyi \& Tyvunka, 2018).

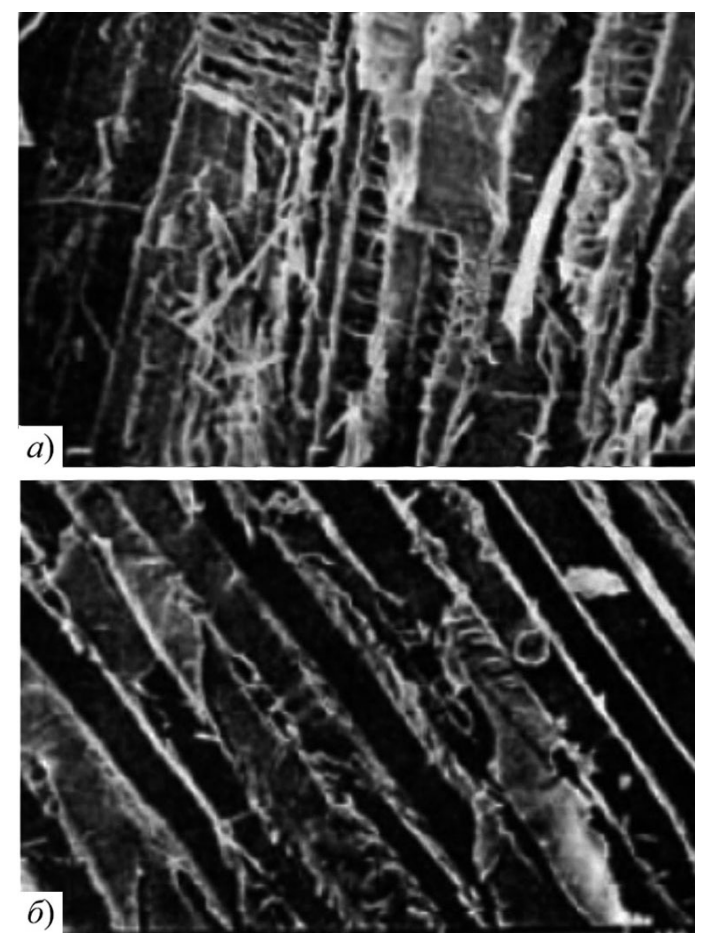

Рис. 2. Структура деревини сосни: $a$ ) необроблена; б) термічно модифікована 
Оброблення деревини підвищеною температурою призводить до зміни як хімічних, так і фізичних їі властивостей. Насамперед це спричиняє термодеструкцію геміцелюлози. За температури $150{ }^{\circ} \mathrm{C}$ починають з'являтися зміни у деревині, які сприяють покращенню іiї фізико-механічних властивостей. За температури вище $150{ }^{\circ} \mathrm{C}$ фізико-механічні властивості покращуються ще більше. У цьому випадку разом із температурою значну роль відіграють і тривалість витримки, тип агента оброблення, швидкість нагрівання, тиск у системі тощо. Внаслідок цього підвищується довговічність деревини, знижується рівень рівноважної вологості та кислотності, деревина змінює колір - темніє, вивітрюються деякі екстрактивні речовини, рівень розбухання знижується, а термоізоляційні властивості поліпшуються.

Водночас змінюється міцність і твердість деревини, зменшується щільність порівняно 3 немодифікованою, деревина втрачає вагу тощо. За результатами досліджень щільність термічно модифікованої деревини за температури $200{ }^{\circ} \mathrm{C}$ дорівнює $550 \mathrm{\kappa r} / \mathrm{M}^{3}$, а за температури $220{ }^{\circ} \mathrm{C}-$ близько $500 \mathrm{\kappa г} / \mathrm{m}^{3}$.

Міцність деревини і щільність $є$ взаємопов'язаними показниками, що значною мірою буде залежати від вмісту вологості в деревині. Тому деякі характеристики міцності будуть змінюватись із зміною вологості. Варто зазначити, що міцність термічно модифікованої деревини збільшується, оскільки рівень рівноважної вологості значно нижчий. Разом 3 тим, модуль пружності змінюється не істотно. Якщо температура оброблення $200{ }^{\circ} \mathrm{C}$, то модуль пружності становить $14000 \mathrm{H} / \mathrm{Mm}^{2}$, а за температури $220^{\circ} \mathrm{C}-13000 \mathrm{H} / \mathrm{mm}^{2}$.

Твердість термічно обробленої деревини зростає із підвищенням температури оброблення. Для прикладу, за температури оброблення $200^{\circ} \mathrm{C}$ твердість дорівнює $1,6 \mathrm{H} / \mathrm{Mм}^{2}$, а за температури $220^{\circ} \mathrm{C}-1,65 \mathrm{H} / \mathrm{Mм}^{2}$. На колір термічно обробленої деревини впливають час і температура оброблення. Чим вища температура, тим темніший колір. Термічно модифіковану деревину отримують чотирма методами оброблення:

- перегрітою парою за температури $150-200^{\circ} \mathrm{C}$;

- перегрітою парою під тиском;

- гарячим маслом;

- інертним газом, зазвичай азотом за підвищеного тиску i низького вмісту кисню.

Властивості термічно модифікованої деревини:

1) Біологічна стійкість збільшується у $15-25$ разів.

2) Теплопровідність знижується на 20-25\%.

3) Рівноважна вологість зменшується на 40-50 \%.

4) Має розмірну стабільність.

5) Добрі естетичні властивості.

6) Екологічно чистий матеріал.

Це дає змогу використовувати термічно модифіковану деревину під час виготовлення віконних рам, дверей, підлогового покриття, меблевих виробів, стінових панелей, альтанок, садових меблів, облагородження територій поруч басейну, личкування фасадів тощо. Термічно модифікована деревина найпридатніша для жорстких умов експлуатації. У перспективі з термічно модифікованої деревини можна виготовляти музичні інструменти, садово-паркові конструкції, домашні речі, різні архітектурні форми.

3 погляду цільового призначення матеріалу та порід деревини, які використовують для модифікування, цей продукт варто розділити на дві групи: перша - термічно модифікована деревина, що виготовлена зі швидкоростучих порід (береза, осика, тополя); друга - термодеревина цінних листяних порід (дуб, бук, ясен, тощо). Якщо перша група передбачає надання швидкоростучим породам високих споживчих якостей, що наближають їх до цінних порід, а подекуди перевершуючи їх, то друга - це продукція високої цінової категорії, де на перше за значущістю місце виходить ексклюзивність матеріалу, що володіє новими, унікальними характеристиками.

Склеювання термічно модифікованої деревини. Для з'єднання деревини широко використовують склеювання. Це дає змогу збільшувати розміри заготовок із деревини за довжиною, шириною та товщиною, отримувати криволінійні заготовки, використовувати низькосортну деревину та кускові відходи тощо. Важливе значення, на сьогодні, має і склеювання термічно модифікованої деревини. Для прикладу, дедалі актуальнішим стає використання термічно модифікованої деревини як екологічно чистого конструкційного матеріалу у будівництві, зокрема клеєного термобруса, який виготовляють 3 немодифікованої і модифікованої деревини. На рис. 3 показано клеєний брус, який виготовлений із немодифікованої і термічно модифікованої деревини.
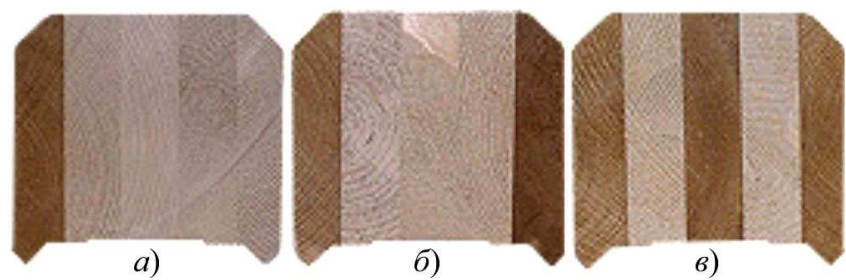

Рис. 3. Клеєний термобрус: $a$ ) 3 однією термоламеллю (захищає фасад від вологи); б) з двома (додатково створює декор внутрішніх стін); в) з трьома (третя ламель є армованим елементом конструкціi).

Цей матеріал викликає зацікавленість у будівництві, де відкриває нові перспективи та можливості. Для прикладу, актуальним $\epsilon$ виготовлення столярно-будівельних виробів, зокрема вікон, де зовнішня ламель виготовлена 3 термічно модифікованої деревини. Така конструкція покращить експлуатаційні властивості вікон. Для виробництва це дасть змогу зекономити кошти, для держави - лісові ресурси, а для споживача - підвищити довговічність виробів.

Для термічного модифікування можна використовувати низькосортні породи деревини, або породи, які не широко використовуються для виготовлення столярнобудівельних та меблевих виробів. Це може бути деревина вільхи, осики, ясена тощо.

Водночас виникає багато проблем із склеюванням термічно модифікованої деревини, що пов'язано із зміною іiі фізико-механічних властивостей. Передусім погіршуються адгезійні властивості термічно модифікованої деревини, що значно зменшує міцність склеювання i конструкції загалом. Клеїв, призначених для склеювання термічно модифікованої деревини, на сьогодні також немає. Вивчення та дослідження цієї проблеми проводилось мало. Тому виникає доволі багато питань щодо склеювання термічно модифікованої деревини, клеїв, якими вона буде склеюватися, iï міцності та довговічності. Ці питання потребують додаткового вивчення та дослідження. 


\section{Перелік використаних джерел}

GOST 18992-80. (2001). Dispersiia polivinilatcetatnaia gomopolimernaia grubodispersnaia. Tekhnicheskie usloviia. Moscow: Izdvo standartov, izmnen., 21 p. [In Russian].

Kshyvetskyi, B. Ya., \& Solonynka, V. R. (2007). Termoplastychni kompozytsii na osnovi polivinilatsetatu (PVA) ta yikh vykorystannia v derevoobrobnii haluzi. Scientific Bulletin of UNFU, 17(6), 9295. [In Ukrainian].

Kshyvetskyi, B. Ya., \& Tyvunka, I. Y. (2018). Mitsnist ta dovhovichnist termoplastychnykh kleiovykh ziednan derevyny. Lviv: TzOV Halytska vydavnycha spilka, 232 p. [In Ukrainian].

Prokopovych, B., Voitovych, I., Haida, S., \& Kshyvetskyi, B. (2002). Tlumachnyi slovnyk z derevoobroblennia. Lviv: Romus - Polihraf, 280 p. [In Ukrainian].

Wood. (2003). ThermoWood: Handbook - Helsinki. Finland: International ThermoWood Association.

B. Ya. Kshyvetskyy, H. M. Datskiv, Yo. V. Andrashek Ukrainian National Forestry University, Lviv, Ukraine

\section{GENERAL INFORMATION ABOUT ADHESIVES, GLUING, AND THERMALLY MODIFIED WOOD}

The analysis of adhesives used for gluing wood in woodworking and furniture manufacturing based on their environmental performance, toxicity, origin, economic feasibility, production methods and applications is presented. Particular attention is paid to thermoplastic polyvinyl acetate adhesives which are currently among the most promising ones for gluing both conventional and thermally modified wood. In the context of encreasing requirements for greening the industry and restrictions on the use of materials containing harmful chemical components, there is a need to develop new methods of wood modification that would be based on the principles of environmental friendliness and resource saving. It is shown that when wood is exposed to a temperature of $180-240{ }^{\circ} \mathrm{C}$, its biological composition undergoes irreversible changes that affect the properties of the final product, in particular: improved shape stability and resistance to high temperatures, absolute resistance to biological damage, high moisture resistance (adsorption properties are 3-5 times lower than in conventional wood), colour uniformity in depth, durability, environmental friendliness, etc. All the abovementioned properties of thermally modified wood determine the versatility of its use: as a structural material resistant to atmospheric influences (street structures, landscape design, bridge construction, moorings, lining of water channels), for external and internal decoration of facades and residential premises, furniture manufacturing, flooring, musical instruments, etc. The range of thermally modified wood application is as extensive as that of conventional wood. In particular, thermally modified wood can be used for constructing small architectural forms, landscape gardening structures. One of the priority areas of scientific research is the study of thermally modified wood which can be used as a material for load-bearing structures, in particular, in the form of composite laminated timber ("glued thermobar") which combines lamellae from modified and conventional wood. The analysis of the effect of changes in the physical-and-mechanical properties of thermally modified wood on the strength and durability of adhesive joints is made. However, there are many problems regarding gluing thermally modified wood, which is associated with changes in its physical-and-mechanical properties. First of all, the adhesion properties of thermally modified wood deteriorate, which significantly reduces the strength of bonding and the structure as a whole. There are no adhesives for bonding thermally modified wood to date. There have been little research and study performed on this problem.

Keywords: adhesives; thermally modified wood; gluing; strength; durability. 